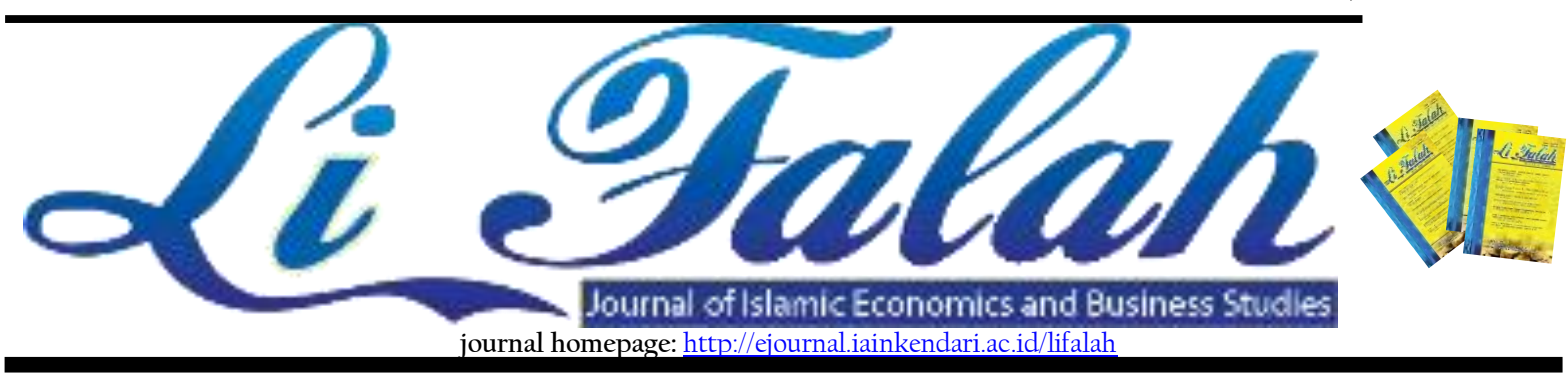

\title{
The Effect of Religiosity, Profit Los And Sharing on Consumer Trust and Intention to Financing in Islamic Bank
}

\section{Rizal Ula Ananta Fauzi ${ }^{{ }^{*}}$,Arman Hj. Ahmad ${ }^{2}$, Zaki Bahrun Ni’am³, Izian Idris ${ }^{4}$, Isabela Indah Puspita Ningrum ${ }^{5}$}

1,5 Faculty of Economic and Business Universitas PGRI Madiun, Indonesia

2. Department of Marketing, Universiti Kuala Lumpur Business School, Malaysia

3 Faculty of Islamic Economics and Business, UIN Satu Tulungagung, Indonesia

4 Sunway University Business School, Malaysia.

${ }^{*}$ Corresponding author: rizalmanajemen@gmail.com

\begin{tabular}{|c|c|}
\hline ARTICLE INFO & A B S T R A C T \\
\hline $\begin{array}{l}\text { Article History: } \\
\text { Received } 10 \text { October } 2021 \\
1^{\text {st }} \text { Received in revised form } 15 \\
\text { November } 2021 \\
2^{\text {nd }} \text { Received in revised form } 9 \\
\text { December } 2021 \\
\text { Available online } 30 \text { December } 2021\end{array}$ & $\begin{array}{l}\text { With a majority Muslim population, Indonesia has } \\
\text { a good market share for Islamic banks. The } \\
\text { existence of conventional banks becomes a } \\
\text { competition to determine the strategy of Islamic } \\
\text { bank managers. This study aimed to examine the } \\
\text { effect of honesty and profit-sharing on trust } \\
\text { mediation on consumer intentions. This study uses } \\
\text { SPSS analysis and the Sobel test to see the role of } \\
\text { mediation. Samples were taken as many as } 384 \\
\text { respondents from the Muslim community. The } \\
\text { analysis results obtained that religiosity } \\
\text { significantly affects consumer trust and intentions. } \\
\text { Profit and loss sharing significantly impacts } \\
\text { confidence and does not affect consumer } \\
\text { intentions. Trust can provide a significant } \\
\text { mediating role. In terms of increasing the factors } \\
\text { that influence consumer intentions, company } \\
\text { managers must build consumer trust, the } \\
\text { opportunity for a religious community to become a } \\
\text { potential target market. }\end{array}$ \\
\hline
\end{tabular}




\section{1. introduction}

Indonesia is a country where the majority of the population is Muslim. The establishment of many pesantren has made the Indonesian people on the island of Java and especially East Java a religious society. Community economic activities are supported by using a financial institution. Among the existing financial institutions are banks. The bank is one of the financial institutions that have an essential role in the economy for the people of Indonesia.

Along with time development, Islamic banks are also expected by Muslims apart from conventional banks. Islamic bank is a banking system developed based on Islamic sharia. Efforts to establish this system are based on the Islamic prohibition on bank interest. Based on the Sharia Banking Statistics (SPS) for the February 2021 period in the OJK (Financial Services Authority) report, which oversees and controls financial and banking institutions, it can be seen that the people of Madiun City intend to finance Islamic banking in Madiun City. Released by the OJK, the data on the financing ratio or the Finance To Deposit Ratio (FDR) can be obtained:

Tabel 1

Rasio Finance To Deposit Ratio(FDR)

\begin{tabular}{cc}
\hline Tahun & Finance To Deposit Ratio (FDR) \\
\hline 2020 & $105,53 \%$ \\
\hline 2021 & $109,62 \%$ \\
\hline
\end{tabular}

Source: OJK Report, accessed 15 May 2021

In table 1, it can be seen that the finance to deposit ratio (FDR) in 2020 is 105.53\%, meaning that it can be seen that the large percentage of people who do financing by saving can be said if every 100 people save, 105 people do the financing. The latest OJK data on the SPS has increased compared to December 2020, which increased by $4.09 \%$. The growth of Islamic banking in Madiun Raya has increased, making Madiun the highest district in East Java in terms of FDR value. The acquisition of this value can be seen in the OJK report as follows:

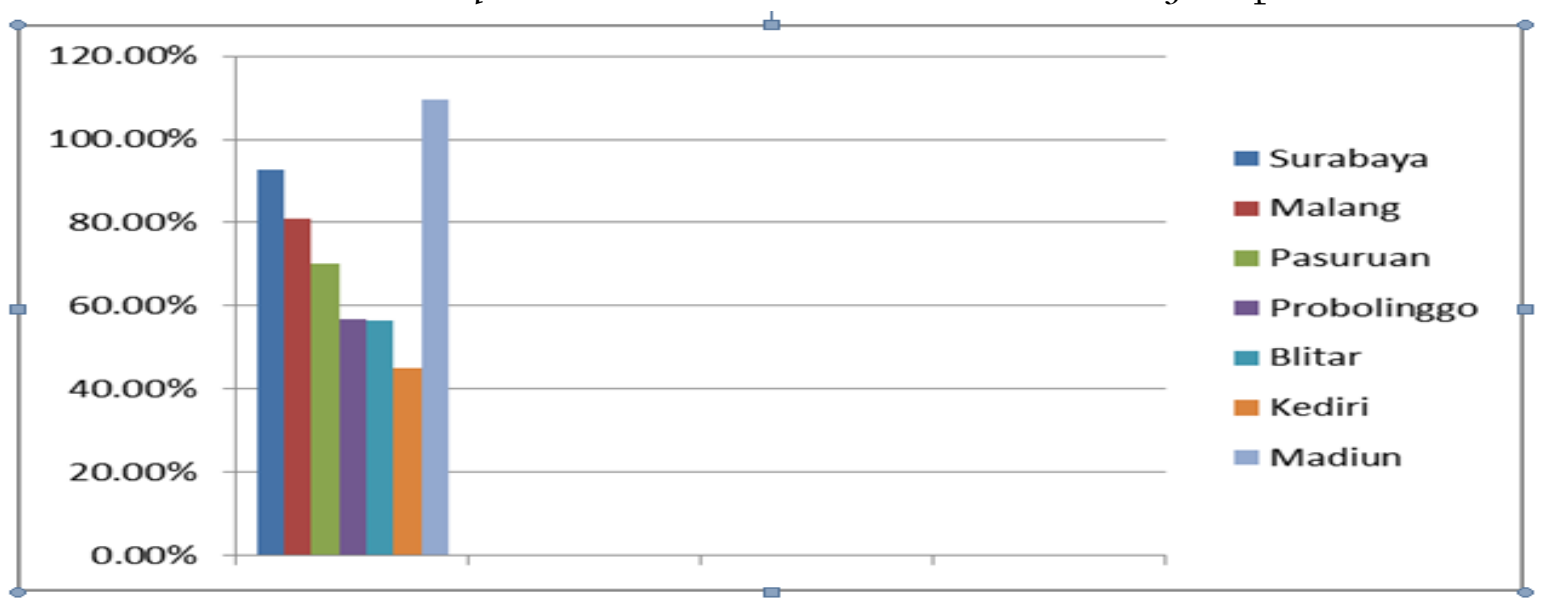

Figure 1. Graph of FDR in East Java - February 2021

It can be seen in Figure 1 that FDR Madiun is in the highest position, precisely at $109.62 \%$, followed by Surabaya City at $92.79 \%$. This data indicates that Madiun has higher financing than other East Java areas of Java. This condition is a good market share opportunity for Islamic banks, and banking managers can create strategies to maintain and develop better. So 
managers need to know the factors that influence consumer intentions to use Islamic banking financing as a basis for decision making. This study tends to determine the factors that affect people's preferences. This study developed a Model Theory of Reasoned Action (TRA). In this theory, the intention is a direct antecedent of behavior that indicates an individual's readiness to engage in a particular behavior (Ajzen, 1980). Based on this theory, behavior is determined by behavior, and intense behavior is influenced by two factors, namely personal attitudes and subjective norms, that reflect social influence. Swastha \& Irawan (2005: 349) show that the factors that influence the interests of consumers are associated with emotional feelings. If someone feels satisfied in purchasing goods or services, he will strengthen purchase intentions. On the contrary, failure to create pleasure will eliminate consumer intentions. Emotions are an essential attitude for rational thinking because emotions provide imperative information about understanding things that are around consumers.

Several studies that developed the TRA model were conducted by Amin et al. (2011); research was conducted to determine customer intention in using Islamic financial services. Several factors influence the choice to use Islamic financing: attitudes, social influences, and prices. Attitude consists of cognition, emotion, and intention. Attitude reflects the relationship between consumers and a product. Lee and Lee's research (2018) determined that social influence predicts purchasing decisions. The role of the religious environment and friends make consideration and input for someone to decide on a product.

Obeid and Kaabachi (2016) say the amount of information about Islamic banks, relative advantages, compatibility, and social factors on consumer intentions to use Islamic banks. Religion expects someone to behave following religious rules so that the principles of sharia will be an impetus for people to choose banking products. The more people consider Islamic banks to be financially profitable, safe, fair, and socially responsible, the more opportunities people can use Islamic banks. The attitude of religiosity, information, and relative profits can influence people's intentions to use Islamic bank products.

According to Omer (1992: 19) in Maisur et al. (2015), Economic behavior is primarily determined by one's faith level. The level of religiosity is an important motivator that encourages someone to use Islamic banking services. The attitude of religiosity is a person's situation that enables him to behave according to his level of obedience. The higher the level of religiosity, it will be wiser to decide to use Islamic banks or conventional banks.

Religiosity is one factor that influences people's intentions because most Madiun people are Muslim. Wahab's research (2013) states that religion is the highest factor influencing people to become bank customers. The study of Newaz et al. 2016; Kaabachi et al. (2016); Yazid (2017); Romdhoni and Ratnasari, 2018; Khotimah, 2018, states that religiosity affects consumer intentions. Meanwhile, Souiden and Rani's (2015) research, Kamarni 2012, and Magfiroh, 2018, religiosity does not affect the preferences of Islamic banks.

Islamic banks use the term Profit and loss sharing in determining the price of Islamic financial transactions because the concept of interest is prohibited in Islam (Olson and Zoubi, 2008). The application of the principles of Islamic financial institutions has made the main difference between Islamic banks and conventional banks related to the prohibition of interest on Islamic 
banks and the interest system used by conventional banks. The presence of a banking profitsharing system must be the best alternative for realizing social welfare and public interest. A profit-sharing system is a system where there is a mutual agreement in carrying out commercial activities - profit and loss sharing as a factor that influences people's intentions towards Islamic banks. The Profit and loss sharing system explains that banks are free from interest, which some think is usury. The existence of a Profit and loss sharing system will affect people's intentions to use banking products. This finding follows research (Kurniawati, (2012); Wahab (2016); Imran and Hendrawan (2017); and Yakin (2016)), which states that Profit and loss sharing affect people's intentions towards Islamic banks.

However, the public's view of the application of Profit and loss sharing has not been fully implemented by Islamic banks in Madiun. Some people view that the applied profit and loss sharing is almost the same as interest in conventional banks, only the terms are changed. This understanding makes Profit and loss sharing does not affect people's intentions. This finding follows Andriani and Halmawati's (2019) research, which states that Profit and loss sharing does not affect the choice to become a customer of a sharia bank.

Factors that influence consumer intentions, namely religiosity, Profit, and loss sharing, on consumer intentions, there is a research gap in the results of previous studies. The researcher indicated that the trust factor could mediate the religiosity factor, Profit and loss sharing, on the community's intentions. The existence of trust is formed from people's attitudes towards a product that comes from public trust in the product. The lower public trust in a product will result in a decrease in available purchases. Trust is an image; people act on their beliefs. The level of public trust is one of the capitals that Islamic banks must consider in Madiun. According to Mowen and Minor (2008: 312), it is stated that trust is all knowledge or information owned by the community and all conclusions drawn by the community on objects, attributes, and benefits.

Fungacova et al. (2016) stated that religious individuals tend to place greater trust in Islamic banks. Lin and Lu (2010) said that belief positively influences people's purchase intentions. People intend to purchase if they believe that the transaction to be carried out will provide value following people's expectations. Hong and Cha (2013) believe that purchases are dominated by by-products that produce a low level of financial risk. The community believes that every transaction carried out requires a fee. In general, the community tries to obtain a low price. Rosdiana and Haris' research (2016) states that trust positively affects people's intentions. Wulandari and Ekawati (2015) state that belief positively affects purchase intention. Several studies have shown the role of faith in forming a relationship between two parties in a transaction. Trust can influence people's decisions in determining their intentions and choices by looking at the direct influence between existing variables and answering the research gap between independent and dependent variables with trust as a mediation used as a novelty in this study. 


\section{Theoretical Review}

\subsection{Intention}

According to Kotler (2005: 15), expressing intention is a behavior that shows a person's desire to purchase in response to an object. Nugroho (2013: 342) describes purchase intention as an integration stage that combines ideas to assess two or more alternative behaviors and choose one of the objects. In this position, intention occurs before people make a purchase decision. Stimuli that arise and comparisons between products and companies become one of the supporters of purchasing decisions-community intention, which is a person's feeling of interest in something by combining knowledge and object comparison. The public's intention in financing at the bank is the public's desire to borrow capital from the bank.

Several previous studies by Ali et al. (2017) stated that attitudes positively affect people's intentions. Kakeeh et al. (2019) expand on the factors influencing people's perspectives. The study results show that attitudes and awareness affect preferences directly while image, awareness, compliance, and individualism of Shariah affect attitudes directly and intentions that are indirectly mediated by attitudes. Lajuni et al. (2017) developed the TRA theory with attitudes, government support, product prices, religious obligations, and social influences that affect people's intentions to use Islamic bank products. Several studies have focused on customers' sustained intention to use Islamic banks and the effects of religious motives and attitudes on preferences. Several studies have looked at several criteria that influence customer intentions to use Islamic banks or Islamic financial products (Taib et al., 2008; Amin et al. 2011; Souiden and Rani 2015; Newaz et al. 2016). The existence of intentions plays an essential role in viewing consumer behavior towards Islamic banks.

\subsection{Religiosity}

Religiosity is defined to the extent that a person has been involved in his religion and teachings, such as individual attitudes and behaviors that reflect his commitment (Johnson et al., 2001). Religiosity is a belief used as a reference or human guide in balancing behavior between the world and the hereafter as a means of getting closer to God. People who have a high attitude of religiosity try to carry out every activity, whether worship or human relations, according to the guidance of his religious teachings. Religiosity is carried out in all life activities because religion regulates the field of ritual worship and regulates and influences all aspects of life.

The attitude of religiosity can affect people's beliefs. Khraim (2010) examined cultural and sub-cultural variables and focused on religious elements because religion plays an essential role in influencing social behavior. Fungacova et al. (2016) stated that religious individuals trust banks. They are more confident in using Islamic banks than conventional banks. Research by Kaakeh and Hasan (2018) states that religious motivation factors affect using Islamic banking. Hanudin et al. (2011) found that religiosity was related to using Islamic financing. So that religion plays a role in people's decisions to use Islamic products. From theoretical studies and previous research, the following hypotheses can be drawn:

Hla. religiosity affects trust

Hlb. Religiosity affects intentions 


\subsection{Profit and loss sharing}

According to the community, the profit-sharing system is the public's perception that this profit-sharing system is more in line with the sharia concept, a more profitable principle, and has made sense of justice for all parties. Profit and loss sharing is the distribution of profits earned on activities between the bank and the customer-agreement in carrying out cooperation. The benefit from both parties, the bank, and the customer, is decided based on a mutual understanding.

The concept of Profit and loss sharing can influence people's trust and intentions in transactions. The community's view of the profit-sharing system is more consistent with religious principles, more profitable, and has fulfilled a sense of justice for all parties. According to Ali et al. (2015), the price/cost factor harms intention. Aghekyan-Simonian et al. (2012) found that public perception of financial risk affects purchase intention. In addition, Hong and Cha (2013) believe that purchases are dominated by by-products that produce a low level of financial trouble. The story of fees that must be paid is a risk the community accepts. This finding shows that people are trying to find the minor possible financial risk in transactions. From theoretical studies and previous research, the following hypotheses can be drawn:

H2a. Profit and loss sharing affects trust

H2b. Profit and loss sharing affects intentions

\subsection{Trust}

According to Peppers and Rogers (2004: 43), trust is a party's belief in the reliability, durability, and integrity of the other party in the relationship. Trust is a hope that individuals maintain with promises and words from trusted people. Trust is generally considered an essential element because it can maintain a long-term relationship, in this case, the customer relationship with the bank. Trust can effectively minimize customer perceptions of uncertainty and risk. Lin and Lu (2010) state that trust positively influences purchase intentions in the community. The community's belief can increase interest in using the products offered. However, public trust must be supported by the existing reality. Saunders et al. (2014) found that trust and distrust evaluate society. Because people will try to consider every transaction made, people intend to purchase if they believe the transaction to be carried out will provide value following their expectations. From theoretical studies and previous research, the following hypotheses can be drawn:

H3 trust affects the intention 
From several previous studies and theoretical studies, the following conceptual framework can be built:

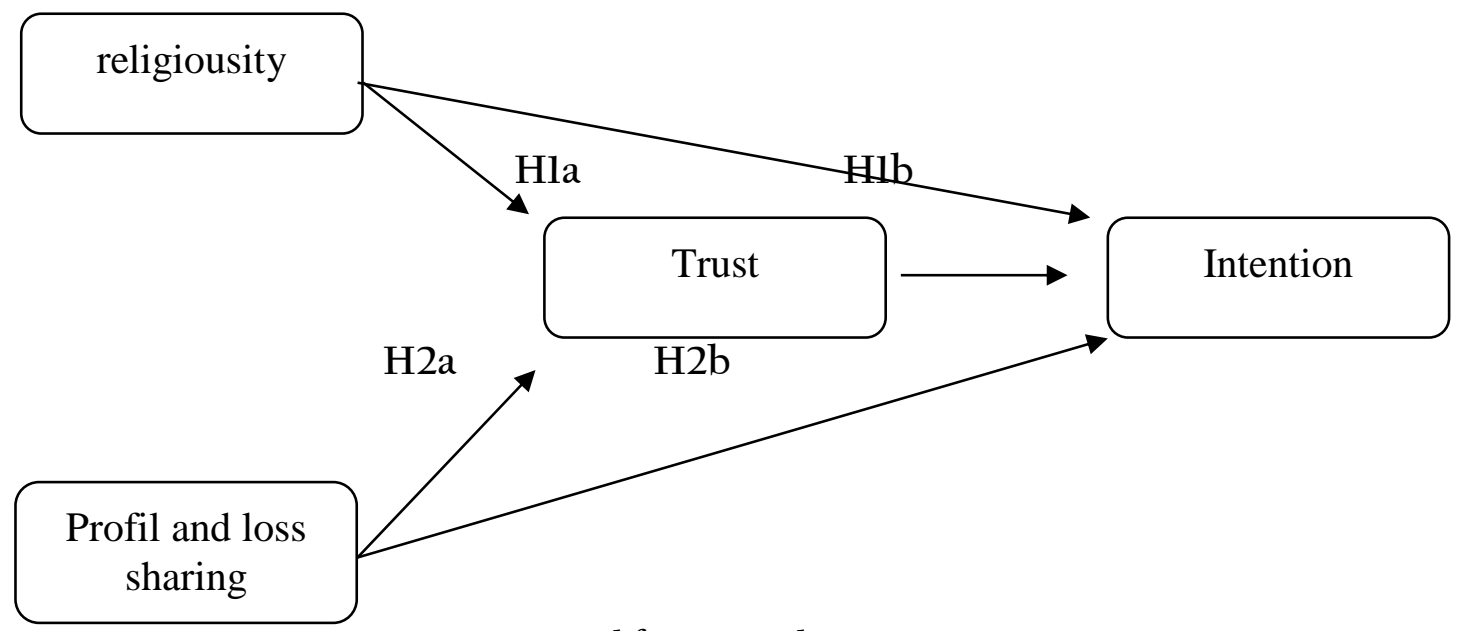

Figure 2. Conceptual framework

\section{Methodology}

This study uses a quantitative research approach. This research was conducted in Madiun to see the attitude of the Muslim community in Madiun related to intentions towards Islamic banks. The population used in this study is the Muslim community in Madiun. Because the number of population is unknown, the researcher to take samples using the Rao Purba formula as follows:

$$
\mathrm{n}=\frac{\mathrm{Z}^{2}}{4(\mathrm{Moe})^{2}}
$$

With a confidence level of $95 \%$ or $Z=1.96$. And a more of $5 \%$, the number of samples can be determined as follows:

$$
\begin{aligned}
& \mathrm{n}=\frac{1,96^{2}}{4(0,05)^{2}} \\
& \mathrm{n}=\frac{3,8416}{0,01} \\
& \mathrm{n}=384,16 \sim 384
\end{aligned}
$$

From the calculation obtained a sample of 384 respondents. The sampling technique used in this study is purposive sampling, where the researcher determines the criteria for selecting respondents according to the needs of the study. To measure the variables, the researcher refers to the theory used previously.

1. Religiosity was measured according to Newaz et al. (2016), namely Religious Beliefs, Practices, Knowledge, Experience, Consequences

2. Profit and loss sharing is measured according to Maisur (2015) and Hasan (2003:48), namely Profitable, Fair, and Transparency

3. Trust is measured according to Wiedenfels (2009) and Zaheer and Bachmann (2006), namely Benevolence (kindness), Competency, Integrity (integrity).

4. Consumer intentions are measured according to Newaz (2016) and Ferdinand (2006), namely transactional intentions, preferential intentions, exploratory requests, future intentions 
There are several tests carried out in this study. Instrument testing uses validity and reliability tests to see the quality of the questionnaire question items. A classical assumption test is done to see the feasibility of the data to perform a multiple regression test. And then, the Sobel test was carried out to see the significant role of mediation.

\section{Results}

From the questionnaire data, the following data were obtained:

Table 2. Description of respondents

\begin{tabular}{|c|c|c|}
\hline \multirow[t]{2}{*}{ Gender } & Male & 289 \\
\hline & Female & 95 \\
\hline \multirow[t]{6}{*}{ Age } & $30-35$ years old & 21 \\
\hline & $36-40$ years old & 94 \\
\hline & 41-45 years old & 147 \\
\hline & $46-50$ years old & 81 \\
\hline & 5l-55 years old & 34 \\
\hline & $56-60$ years old & 7 \\
\hline \multirow[t]{5}{*}{ Education } & Junior high school (SMP) & 22 \\
\hline & High school (SMA) & 121 \\
\hline & Diploma & 63 \\
\hline & Bachelor & 169 \\
\hline & Postgraduate & 9 \\
\hline \multirow[t]{3}{*}{ Employment } & Civil Servants (PNS) & 26 \\
\hline & Private employees & 131 \\
\hline & Entrepreneur & 227 \\
\hline \multirow[t]{5}{*}{ Income } & Less than 15000 & 16 \\
\hline & $1,600,000-2,500,000$ & 96 \\
\hline & $2,600,000-4,000,000$ & 172 \\
\hline & $4,100,000-6,000,000$ & 78 \\
\hline & More than 600,0000 & 22 \\
\hline
\end{tabular}

From table 2, it is obtained data that the average person who fills out questionnaires related to financing intentions in Islamic banks is male with a total of 289 , in terms of age between 4145 years with a total of 147 , the most education is undergraduate graduates with a total of 169 people. , in terms of employment, the highest is entrepreneurial work with 227 and the highest income between 2,600,000-4,000,000 with 172 people.

\subsection{Instrument test}

The instrument test was carried out to see the quality of the questionnaire that had been made. A good quality questionnaire must meet the validity and reliability tests.

\section{a. validity}

A validity test was carried out to see if the questionnaire statement items had met the valid criteria. The results of the SPSS analysis are shown in Table 3 below. 
Table 3. Normality test

\begin{tabular}{|c|c|c|}
\hline Variable & Item & r value \\
\hline \multirow[t]{10}{*}{ Religiosity } & a. Religious beliefs affect life's affairs & $0.851^{* *}$ \\
\hline & b. Religious beliefs my approach to life & $0.903^{* *}$ \\
\hline & a. Enjoy working in my religion & $0.914^{* *}$ \\
\hline & b. Growing up in understanding my religion. & $0.928^{* *}$ \\
\hline & a. Spending a period of time in my religion & $0.900^{* *}$ \\
\hline & b. Reading books and magazines about my religion & $0.870^{* *}$ \\
\hline & a. Religion is very important to me & $0.910^{* *}$ \\
\hline & b. I enjoy time with people of religion & $0.921^{* *}$ \\
\hline & a. Having influence decisions in religion. & $0.886^{* *}$ \\
\hline & b. Making financial contributions to religion & $0.863^{* *}$ \\
\hline \multirow[t]{20}{*}{$\begin{array}{l}\text { Profit and loss } \\
\text { sharing }\end{array}$} & $\begin{array}{l}\text { a. Profit and loss sharing will be profitable compared to } \\
\text { interest }\end{array}$ & $0.752^{* *}$ \\
\hline & b. Profit and loss sharing is not like usury/interest & $0.748^{* *}$ \\
\hline & a. The results will be paid according to the agreement & $0,705^{* *}$ \\
\hline & b. Banks do not determine high Profit and loss sharing & $0.732^{* *}$ \\
\hline & a. Banks make clear deals & $0.661^{* *}$ \\
\hline & b. Customers know the terms of Profit and loss sharing & $0.762^{* *}$ \\
\hline & a. Bank prioritizes the interests of customers & $0.924^{* *}$ \\
\hline & b. Banks provide easy terms & $0.907^{* *}$ \\
\hline & $\begin{array}{l}\text { a. Islamic banks will provide customer security in } \\
\text { transactions }\end{array}$ & $0.890^{* *}$ \\
\hline & b. Banks provide good service & $0.879^{* *}$ \\
\hline & a. Islamic banks will keep their promises & $0.653^{* *}$ \\
\hline & b. Banks are responsible for customers & $0.879^{* *}$ \\
\hline & a. I will do Islamic bank financing & $0.858^{* *}$ \\
\hline & b. Interested in doing Islamic bank financing & $0.828^{* *}$ \\
\hline & a. Choosing a Sharia Bank over other banks & $0.685^{* *}$ \\
\hline & b. Sharia Banks are the priority choice. & $0.815^{* *}$ \\
\hline & a. Looking for information about financing principles & $0.837^{* *}$ \\
\hline & b. Find out about the terms of financing & $0.820^{* *}$ \\
\hline & a. I do financing in the future & $0.664^{* *}$ \\
\hline & $\begin{array}{l}\text { b. In the near future, Islamic Bank financing will be carried } \\
\text { out. }\end{array}$ & $0.827^{* *}$ \\
\hline
\end{tabular}

From table 3 , it is obtained that the value of $r$ count $>0.3$, it can be said that the question items that have been made meet the valid criteria. 


\section{b. reliability}

The reliability test was conducted to see whether the questionnaire was reliable and consistent with the respondents. To know the reliability test can be seen in the table below.

Table 4. Reliability test

\begin{tabular}{lll}
\hline \multicolumn{1}{c}{ Variable } & Cronbach's Alpha \\
\hline Religiosity & 0.972 & \\
Profit and loss sharing & 0.964 & \\
Trust & 0.928 & \\
Intention & 0.915 & \\
\hline
\end{tabular}

From table 4, Cronbach's Alpha value > 0.6 can be said to meet the reliability test (Sugiono, 2013).

\section{c. Classic assumption test}

A classical assumption test is used to test whether the data obtained is feasible for regression testing. There are three classical assumption tests: normality, multicollinearity, and multicollinearity.

A normality test was conducted to determine whether the independent variable and the dependent variable were normally distributed or not. The normality test can be seen in the standard p test plot in Figure 3. It is known that the data spread around the line and follows the direction of the line. It can be said that the data is typically distributed

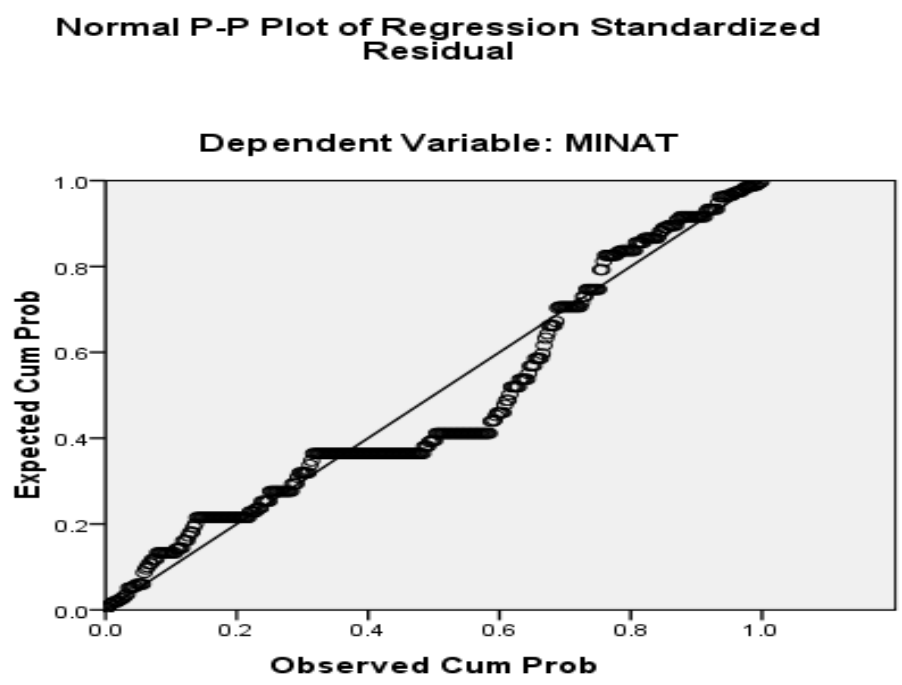

Figure 3. Normality test

Furthermore, good data is data that does not occur multicollinearity. The analysis results obtained a tolerance value $>0.10$ and vice versa. If $\mathrm{VIF}<10$, then there is no multicollinearity. These results can be seen in Table 5 below. 
Table 5 multicollinearity test

Collinearity Statistics

Model

Tolerance

VIF

$1 \quad$ (Constant)

\begin{tabular}{lrr}
\hline Religiusitas & .807 & 1.239 \\
\hline Profit and loss sharing & .862 & 1.161 \\
\hline Trust & .818 & 1.222
\end{tabular}

From table 5, the tolerance value is $>0.10$, and vice versa if $\operatorname{VIF}<10$, then there is no multicollinearity.

The last classic assumption test is the heteroscedasticity test, a regression test to see an unequal variance between observation residuals and other observations. To know the heteroscedasticity test, see the diagram below.

Scatterplot

Dependent Variable: y

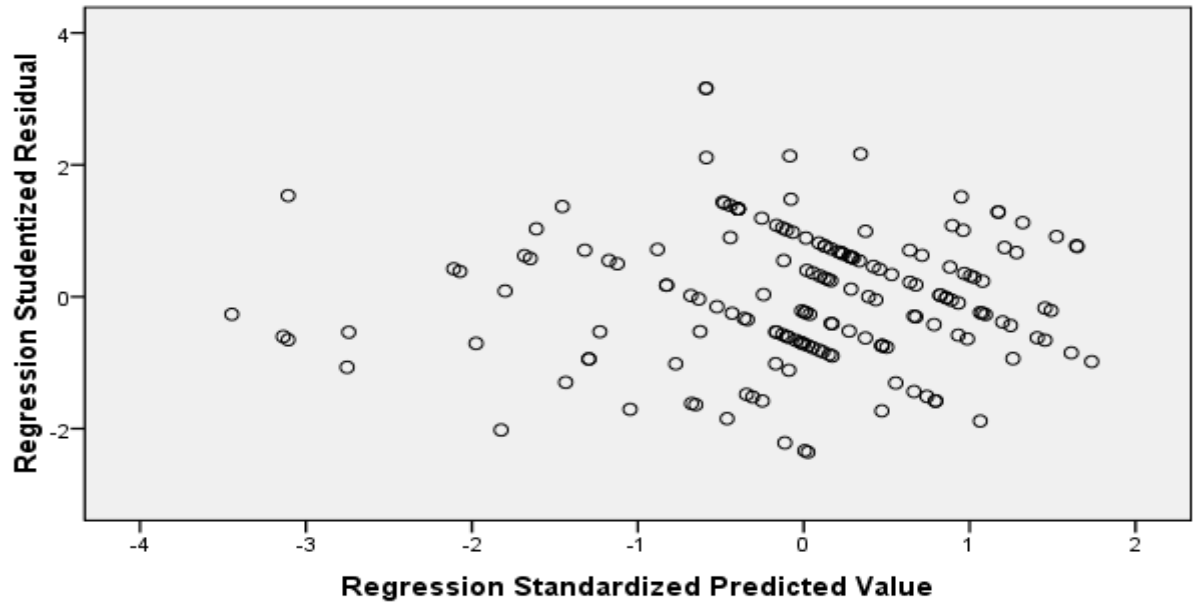

Figure 4. Heteroscedasticity test

From Figure 4. The results show no clear image pattern, and in the image, there are dots scattered above and below the number 0 on the Y-axis. Thus, the test results show no heteroscedasticity. The analysis of a good regression model is free of heteroscedasticity.

\subsection{First Regression}

The first regression analysis looks at the effect of the independent variable on the dependent variable. In the first regression, the trust variable became the dependent variable while religiosity and Profit and loss sharing became the independent variables. From the results of SPSS analysis obtained: 
Table 6. Regression equation 1

\begin{tabular}{|c|c|c|c|c|c|}
\hline \multirow[b]{2}{*}{ Model } & \multicolumn{2}{|c|}{$\begin{array}{l}\text { Unstandardized } \\
\text { Coefficients }\end{array}$} & \multirow{2}{*}{$\begin{array}{c}\text { Standardized } \\
\text { Coefficients } \\
\text { Beta }\end{array}$} & \multirow[b]{2}{*}{$\mathrm{T}$} & \multirow[b]{2}{*}{ Sig. } \\
\hline & B & Std. Error & & & \\
\hline $1 \quad$ (Constant) & 2.368 & .188 & & 12.628 & .000 \\
\hline Religiosity & .275 & .042 & .321 & 6.562 & .000 \\
\hline Profit andloss sharing & .179 & .045 & .196 & 4.013 & .000 \\
\hline
\end{tabular}

From the results of the analysis in Table 6, it can be seen that the significant coefficient of religiosity is $0.00<0.05$, and the $\mathrm{B}$ value is 0.321 . This data means that religiosity significantly affects consumer intentions of 0.321 . While the value of the coefficient of Profit and loss sharing is $0.00<0.5$ with a B value of 0.196 , it can be said that Profit and loss sharing has a significant effect on consumer intentions.

\subsection{Second Regression}

The second regression analysis looks at the effect of the independent variable on the dependent variable. In the second regression, consumer intention becomes the dependent variable, while religiosity, Profit and loss sharing, and trust become the independent variables. From the results of SPSS analysis obtained:

Table 7. Regression equation 2

$\begin{array}{cc}\text { Unstandardized } & \text { Standardized } \\ \text { Coefficients } & \text { Coefficients }\end{array}$

Std.

\begin{tabular}{|c|c|c|c|c|c|c|c|c|}
\hline \multicolumn{2}{|c|}{ Model } & B & Error & Beta & $\mathrm{T}$ & Sig. & e & VIF \\
\hline \multirow[t]{4}{*}{1} & (Constant) & 1.975 & .189 & & 10.432 & .000 & & \\
\hline & Religiosity & .230 & .038 & .298 & 6.123 & .000 & .807 & 1.239 \\
\hline & $\begin{array}{l}\text { Profit and loss } \\
\text { sharing }\end{array}$ & .071 & .039 & .087 & 1.842 & .066 & .862 & 1.161 \\
\hline & Trust & .256 & .043 & .284 & 5.883 & .000 & .818 & 1.222 \\
\hline
\end{tabular}

From the results of the analysis in Table 7, it can be seen that the significant coefficient of religiosity is $0.00<0.05$. And the $B$ value is 0.296 , which means that religiosity has a significant effect on consumer intentions of 0.296. The value of the Profit and loss sharing coefficient is $0.066>0.5$ with a value of 0.087 . It can be seen that Profit and loss sharing has no significant effect on intention. While the value of the trust coefficient is $0.000<0.05$ with a value of 0.284 , it can be seen that trust has a significant effect on intentions of 0.284 . 


\subsection{Mediation test}

Furthermore, to see whether the influence is significant or not, the Sobel test is used as follows:

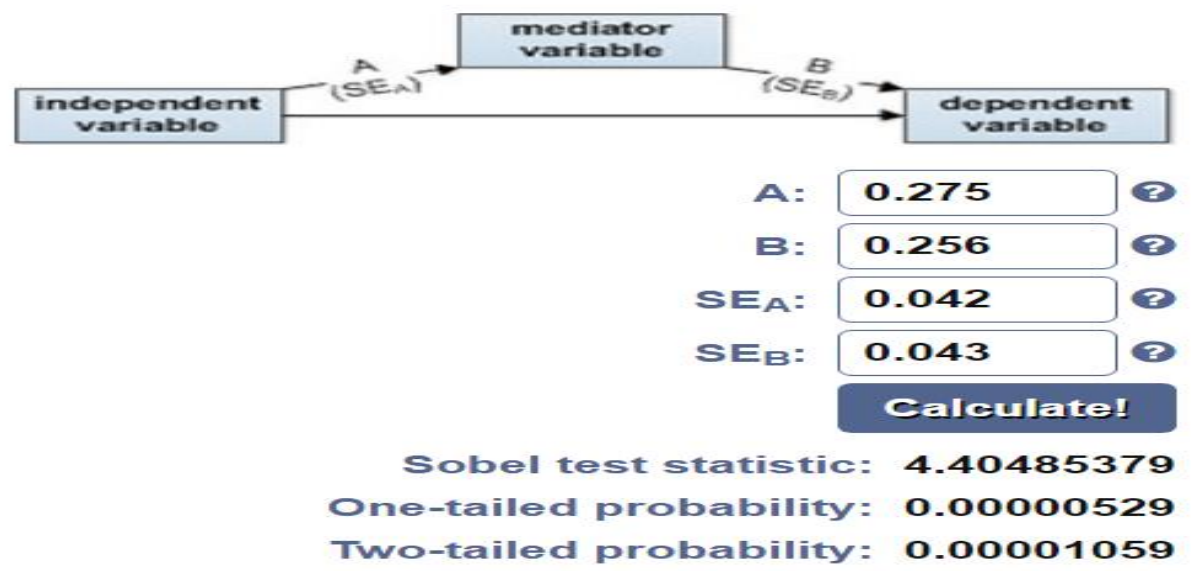

From the Sobel test calculation results, it is obtained that the number is $4.4048>1.96$, so trust significantly provides a mediating role for the influence of religiosity on consumer intentions. Furthermore, to see the effect of Profit and loss sharing on purchase intention mediated by trust, it can be seen from the direct effect of 0.087 . In contrast, the indirect effect of $0.196 \mathrm{x}$ $0.284=0.056$, then the total effect is the value of direct influence plus indirect influence. 0.087 $+0.056=0.143$. These results indicate that the effect of Profit and loss sharing on consumer intentions through trust is 0.143 . Furthermore, to see whether the effect is significant or not, the Sobel test is used as follows:

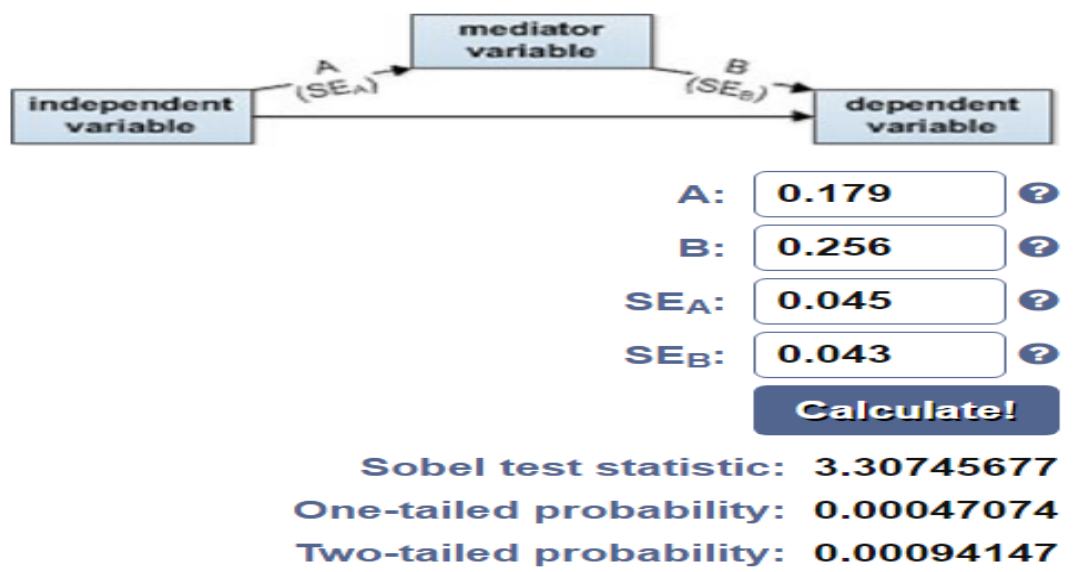

From the Sobel test calculation results, the number 3.3074> 1.96 means that trust significantly provides a mediating role for the effect of Profit and loss sharing on consumer intentions.

\section{Discussion}

The results of hypothesis testing that have been carried out show that religiosity has a significant effect on trust. If a person's religiosity increases, public trust will also increase towards Islamic banks. This finding indicates that the people's religiosity level in Madiun can increase public confidence in the Islamic Bank financing process. Religiosity is an attitude possessed by someone who tries to carry out the religious rules he has learned. The attitude of religiosity can influence a person's intentions and make decisions. The attitude of religiosity will implement in life and become a person's character. The advantages of Islamic banks that run the Islamic banking system are the main opportunities in the community's choice. 
The existence of a religion that teaches the afterlife makes the motivation to live life in this world. This finding requires understanding and sufficient religious knowledge as a provision in life. Improving a better attitude of religiosity requires the support and motivation of the community to learn and experience understanding about their religion. Research by Usman et al. (2017) stated that religiosity affects people's beliefs. A study by Abou-Yioussef et al. (2015) says that religious beliefs play an essential role in people's decisions regarding Islamic banking products and services. The role of religion can create trust in Islamic products.

The results of hypothesis testing that have been carried out show that religiosity has a significant effect on people's intentions. This finding means that if religiosity increases, it will increase people's intentions. People who have high religiosity tend to choose products towards the corridor of their religion. This finding is because they desire to live life following the religious teachings they believe in religious values. People will use Islamic bank financing more, making Islamic banks a top priority in overcoming their economic problems. Religiosity is a strong determinant of interest in using Islamic banking. Lajuni et al. (2017) argue that the more one is afraid of divine punishment, the more one will develop a favorable perception of Islamic banking. Hanudin et al. (2011) found religiosity was significantly related to the intention to use Islamic financing. Echchabi and Olaniyi (2012) state that choosing an Islamic bank is due to the religious motivation of the customer. The higher a person's religiosity, the higher the motivation of the community to use Islamic banking. This finding aligns with Kaakeh et al.'s (2018) research that religious motivation factors affect using Islamic banking.

The results of the hypothesis test that have been carried out show that the perception of Profit and loss sharing has a significant effect on public confidence in financing Islamic banks in Madiun.

Empirically find that public perceptions of the Profit and loss sharing system influence public trust in Madiun in the funding of Islamic banks. The general perception of the Profit and loss sharing of Islamic Bank financing, which is fair, follows the public's perception of providing trust. Antonio (2001: 90) states that Profit and loss sharing is a division of business results between capital owners and capital managers with principles in the Islamic economic system. In the Profit and loss sharing system, there is an agreement determined by the bank and the community. This finding supports the principle of Profit and loss sharing that can provide public confidence in justice and benefits for the community. Following Rahmawaty (2014) stated the reasons put forward related to Profit and loss sharing are basically: (a) following Islamic religious principles, (b) it is beneficial to customers, and (c) the Profit and loss sharing ratio has fulfilled a sense of justice. The existing methods can create public trust in the profitsharing system offered by Islamic banks.

The results of hypothesis testing that have been carried out show that Profit and loss sharing has no significant effect on people's intentions. The low public trust in the ratio distribution and Profit and loss sharing that is not under the community's wishes will reduce the public's intention. The public has less knowledge about the provisions of the profit-sharing concept of Islamic banks, creating the public's desire to seek accurate information. Profit and loss sharing makes costs in transactions at Islamic banks become something important in the transaction process. People in general still think twice about the size of the fees to be paid. 
Profit and loss sharing is a fee or price previously agreed upon by the customer and the bank. Rahman (2005) stated that pricing is the key predictor of Islamic banks' interest in banking products. The same conclusion can be drawn from studies by Yu (2012), Luarn and Lin (2005), which state that costs affect people's interests. This finding explains that the greater the perceived financial cost, the less interest in choosing Islamic banking products. Thus, although the concept of Profit and loss sharing offered is free of usury, if the ratio value to be paid is high, it will affect consumers' intentions to finance Islamic banks.

The results of hypothesis testing that have been carried out show that trust significantly influences people's intentions. This finding means that if public trust increases, the intention of the community will also increase. Creating trust is the main thing in a relationship because faith can make a good relationship. Someone who has confidence in the other party will agree and follow what he says. According to Garbarino and Johnson (1999), trust is essential in a competitive environment. Research by Lin and Lu (2010) states that trust positively influences people's purchase intentions. People will make Islamic banks a priority when people believe in Islamic banks. Trust is motivation and consideration for someone to behave.

\section{Mediation evaluation}

The influence of religiosity on people's intentions through public trust in Islamic banks proves correct. It shows that trust mediates the relationship between religiosity and community intentions. Benevolence indicator (kindness) becomes an essential role for faith because Islamic Banks strive to meet the needs expected by the community. The position of public trust in the Mumalat bank is getting better, with public confidence in Islamic banks that try to run companies with Islamic concepts following religious teachings. This belief in the Islamic system can increase the role of community religiosity on people's intentions in financing Islamic banks. The community believes that Islamic banks will develop by looking at the majority of Islamic Madiun people who make potential target markets and a conducive and religious environment so that the role of the environment can influence a person's attitude to make decisions.

The religious environment can increase one's religious attitude so that the existing attitude can improve people's intentions towards Islamic banks. People with higher religiosity will have a high level of trust. The attitude of religiosity can influence people's intentions in financing Islamic banks. This trust can strengthen people's intentions to do financing because religiosity and trust can create people's intentions. Usman et al. (2017) stated that religiosity affects people's beliefs. People with higher religiosity also have higher trust in Islamic banks. Jamal (2003) religious beliefs affect people's feelings and consumer attitudes. Abdul Rahim and Robson (2017) state that religion is the essential motive for Muslims for Islamic banking, even though customers are not aware of the mechanisms and contracts used by Islamic banks.

The research results on Profit and loss sharing on people's intentions through public trust in Islamic banks show that trust significantly mediates the relationship between Profit and loss sharing and community intentions. Kotler (2005:218) argues that belief is a picture of the thoughts held by someone about the concept of something. This finding means that a person's belief in Profit and loss sharing or fees set by Islamic banks will undoubtedly influence the community to behave because of their beliefs. When trust in Profit and loss sharing has a 
positive influence, it will increase people's intentions and vice versa if public confidence in negative Profit and loss sharing will reduce people's preferences. Dusuki and Abdullah (2007) suggest that the costs and benefits of Islamic banks' products and services are essential factors to increase customer intention to use Islamic banking products and services.

\section{Conclusion}

Consumers in choosing a product will evaluate. They will think about the benefits and advantages that will be obtained. Many factors influence consumers' intention to do financing in Islamic banks. From the research results, it was found that religiosity affected consumer trust and intentions. The attitude of religiosity will be a person's motivation related to religious products.

Meanwhile, Profit and loss sharing affects trust and does not affect consumer intentions. Consumers related to the costs incurred are still thinking about doing it. The greater the costs incurred, the smaller the consumer's intention. The role of trust in mediating religiosity and Profit and loss sharing on consumer intentions has a significant influence. Trust can stabilize a person's behavior. Thus, it can be implemented that trust can support the factors that influence consumer intentions. A manager must build consumer trust to stay ahead of the competition. 


\section{REFERENCE}

Abdullrahim, N. dan J. Robson. 2017. The Importance Of Service Quality In British Muslim's Choice Of An Islamic Or Non-Islamic Bank Account. Journal of Financial Services Marketing 22 (2): 54-63

Abou-Youssef, M., W. Kortam, E. Abou-Aish dan N. El-Bassiouny. 2015. Effects of Religiosity On Consumer Attitudes Toward Islamic Banking In Egypt. International Journal of Bank Marketing 33(6): 786-807.

Ali, M., S.A. Raza, dan C.H. Puah .2015. Factors Affecting Intention To Use Islamic Personal Financing In Pakistan: Evidence From The Modified TRA Model. IQRA University, University Malaysia Sarawak MPRA Paper 66023 : 1-28

Ali, A., G. Xiaoling, M. Sherwani, dan A. Ali. 2017. Factors Affecting Halal Meat Purchase Intention. British Food Journal 119(3): 527-541

Andriani, G. F., dan Halmawati. 2019. Pengaruh Bagi Hasil Kelompok Acuan Kepercayaan Dan Budaya Terhadap Niat Menjadi Nasabah Bank Syariah. Jurnal Eksplorasi Akuntansi $1(3): 1322-1336$

Aghekyan, S. M., S. Forsythe, dan W. S. Chattaraman. 2012. The Role Of Product Brand Image And Online Store Image On Perceived Risks And Online Purchase Intentions For Apparel. J. Retail. Cons. Serv. (19): 325-331.

Ajzen, I. 1980. From Intentions To Actions: A Theory Of Planned Behavior. In: Kuhl, J., Beskmann, J. (Eds.), Action Control: From Cognition to Behavior. Springer. New York: 11-39.

Amin, H., A. R. A. Rahman, S. L. Sondoh, dan A. M. C. Hwa. 201l. Determinants Of Customers Intention To Use Islamic Personal Financing The Case Of Malaysian Islamic Banks. Journal Of Islamic Accounting And Business Research 2 (1): 22-42

Antonio, M. S, 2001. Bank Syariah Dari Teori Ke Praktik, Cetakan Pertama. Gema Insani Press. Jakarta

Dusuki, A.W. dan N. Abdullah. 2007. Why do Malaysian Customers Patronize Islamic Banks? International Journal of Bank Marketing 25 (3): 142-160.

Echchabi, A. dan H. Olaniyi. 2012. Empirical Investigation Of Customers' Perception And Adoption Towards Islamic Banking Services In Morocco. Middle-East Journal of Scientific Research 12 (6): 849-858.

Ferdinand, A. 2006. Metode Penelitian Manajemen. Edisi Kedua. Badan Penerbit Universitas Diponegoro. Semarang.

Fungacova, Z. I. Hasan dan L.Weill. 2016. Trust In Banks BOFIT - Institute for Economies in Transition Bank of Finland (7):1-44

Garbarino, E. dan M.S. Johnson, 1999. The Different Roles Of Satisfaction, Trust, And Commitment In Customer Relationships. Journal of Marketing 63 (2): 70-87. 
Hanudin, A., A. R. A. Rahim, , S.L. Sondoh, , S. Liason, dan A.M.C. Hwa, 2011. Determinants Of Customers' Intention To Use Islamic Personal Financing: The Case Of Malaysian Islamic Banks. Journal of Islamic Accounting and Business Research 2( 1): 22-42.

Hasan, M. A. 2003. Berbagai Macam Transaksi Dalam Islam (Fikih Syariah). Cetakan Kedua . PT Raja Grafindo Persada. Jakarta

Hong, B. dan H.S.Cha. 2013. The Mediating Role Of Consumer Trust In An Online Merchant Inpredicting Purchase Intention. Int. J. Inform. Manag. (3): 927- 939

Imran dan B. Hendrawan. 2017. Pengaruh Persepsi Masyarakat Batam Tentang Bank Syariah Terhadap Minat Menggunakan Produk Bank Syariah. journal of business administration 1 (2): $209-218$

Jamal, A. 2003. Marketing In A Multicultural World: The Interplay Of Marketing Ethnicity And Consumption. European Journal of Marketing 37 (11/12): 1599-1620.

Johnson, B. R., S. J.Jang, D. B. Larson, dan S.D. Li. 2001. Does Adolescent Religious Commitment Matter? A Reexamination Of The Effects Of Religiosity On Delinquency. Journal of Research in Crime and Delinquency 38 (1): 22-43.

Kaabachi, S. dan H. Obeid. 2016. Determinants Of Islamic Banking Adoption In Tunisia: Empirical Analysis International. Journal of Bank Marketing 34 (7):1069-1091.

Kaakeh. A., dan M. K. Hassan. 2018. Attitude Of Muslim Minority In Spain Towards Islamic Finance. International Journal of Islamic and Middle Eastern Finance and Management 11 (2): $213-230$

Kaakeh, A., M. K., Hassan, dan S.F V. H. Almazor. 2019. Factors Affecting Customers' Attitude Towards Islamic Banking In UAE. International Journal of Emerging Markets.14(4) : 21-34

Kamarni, N. 2012. Faktor-Faktor Yang Mempengaruhi Minat Masyarakat Dalam Berhubungan Dengan Bank Syariah. Di Kota Padang. Jurnal Manajemen dan Kewirausahaan 3(1): $2086-5031$

Khotimah, N. 2018. Pengaruh Religiusitas, Kepercayaan Citra Perusahaan dan Sistem Bagi Hasil Terhadap Minat Nasabah Menabung dan loyalitas Di Bank Syariah Mandiri (Studi Kasus Pada Nasabah Bank Syariah Mandiri Gresik). Jurnal Ilmu Ekonomi \& Manajemen 5 (1): 37-48

Khraim, H.S. 2010. Factor Affecting Jordanian Consumers Adoption Of Mobile Banking Services. International Journal of Business and Social Science 2 (20): 96-105.

Kotler. 2004. Marketing Management. Elevent Edition. Pearson Education . Inc.. Terjemahan B. Molan. 2005. Manajemen Pemasaran. Edisi Kesebelas. Indeks kelompok. Gramedia. Jakarta.

Kurniawati, E. T. 2012. Analisis Pengaruh Profitabilitas Sistem Bagi Hasil Dan Kualitas Layanan Bank Terhadap Niat Nasabah Berinvestasi (Studi Kasus Pada Bank Muammalat Cabang Malang). Jurnal Humanity 7(2): 46 - 55 
Lajuni, N., W.W.P.Ming, Y.Yacob, H. Ting, dan A. Jausin. 2017. Intention To Use Islamic Banking Products And Its Determinants. International Journal of Economics and Financial Issues 7 (1): 329-333.

Lee. J dan Y.Lee 2018. Lee Effects Of Multi-Brand Company CSR Activities On Purchase Intention Through A Mediating Role Of Corporate Image And Brand Image. Journal of Fashion Marketing and Management 22 (3): 387-403

Lin L.Y and C. Y. Lu. 2010. The Influence Of Corporate Image, Relationship Marketing, And Trust On Purchase Intention: The Moderating Effects Of Word-Of-Mouth. Tourism Review 65 (3): 16-34.

Luarn, P. dan H. H Lin. 2005. Toward An Understanding Of The Behavioural Intention To Use Mobile Banking. Computer in Human Behavior 21(6): 873-891.

Maghfiroh, S. 2018. Pengaruh Religiusitas, Pendapatan, Dan Lingkungan Sosial Terhadap Minat Menabung Di Bank Syariah Pada Santri Pesantren Mahasiswa Darush Shalihat. Jurnal Pendidikan dan Ekonomi, 7( 3) : 290-300.

Maisur, M. Arfan, dan M. Shabri. 2015. Pengaruh Prinsip Bagi Hasil, Tingkat Pendapatan, Religiusitas Dan Kualitas Pelayanan Terhadap Keputusan Menabung Nasabah Pada Bank Syariah Di Banda Aceh. Jurnal Magister Akuntansi. 4 (2) : 1-8.

Mowen, J. C. dan M. Minor. 2008. Consumer Behavior 6ed. Prentice-Hall,Inc. New Jersey. Terjemahan. L. Salim. (2009) Perilaku Konsumen. Edisi Keenam. Erlangga. Jakarta

Newaz, F. T., K. S. Fam dan R. R. Sharma. 2016. Muslim Religiosity And Purchase Intention Of Different Categories Of Islamic Financial Product. Journal of Financial Services Marketing 21: 141-152.

Nugroho S. J. 2013. Perilaku Konsumen. Edisi Revisi. PT. Kharisma Putra Utama. Jakarta.

Obeid, H, dan S. Kaabachi. 2016. Empirical Investigation Into Customer Adoption Of Islamic Banking Services In Tunisia. The Journal Of Applied Business Research 32 ( 4): 1243-1256

Olson, D. dan T. A Zoubi. 2008. Using Accounting Ratios To Distinguish Between Islamic And Conventional Banks In The GCC Region. The International Journal of Accounting (43): 45 65.

Peppers, D dan M. Rogers. 2004. Managing Customer Relationships: A Strategic Framework, New Jersey: John Wiley \& Sons, Inc.

Rahman, Z.A. 2005. Competitive Pricing of Islamic Banking. Kuala Lumpur: NST

Rahmawaty, A. 2014. Pengaruh Persepsi Tentang Bank Syariah Terhadap Minat Menggunakan Produk Di BNI Syariah Semarang. Jurnal ADDIN 8 (1):1-15.

Romdhoni A. H dan, D Ratnasari 2018. Pengaruh Pengetahuan, Kualitas Pelayanan, Produk, dan Religiusitas terhadap Minat Nasabah untuk Menggunakan Produk Simpanan pada Lembaga Keuangan Mikro Syariah. Jurnal Ilmiah Ekonomi Islam 4 (2):136-147 
Rosdiana, K. dan I. A. Haris 2016. Pengaruh Kepercayaan Konsumen terhadap Minat beli Produk Pakaina Secara Online. International Journal Of social Science and business 2(3): 169 175

Sounders, M. N., G Dietz, dan A. Thornhill (2014). Trust and distrust: Polar opposites, or independent but co-existing? Human Relations, 67(6) : 639-665

Souiden, N., dan M. Rani. 2015. Consumer Attitudes And Purchase Intentions Toward Islamic Banks: The Influence Of Religiosity. International Journal of Bank Marketing 33 (2): 143-161

Souiden, N., dan M. Rani. 2015. Consumer Attitudes And Purchase Intentions Toward Islamic Banks: The Influence Of Religiosity. International Journal of Bank Marketing 33 (2): 143-161

Sugiyono. 2013. Metode Penelitian Kuantitatif, Kualitatif dan ReD. Alfabeta.CV Bandung:

Swastha, B dan Irawan. 2005. Asas-asas Marketing. Cetakan Kedua. Liberty. Yogyakarta.

Taib, F., T. Ramayah, dan D. A. Razak. 2008. Factors Influencing Intention To Use Diminishing Partnership Home Financing. International Journal of Islamic and Middle Eastern Finance and Management 1(3): 235-248.

Usman, H., P. Tjiptoherijanto, dan I.G.N.agung, 2017.The Role Of Religious Norms, Trust, Importance Of Attributes Andinformation Sources In The Relationship Between Religiosity and Selection Of The Islamic Bank. Journal of Islamic Marketing 8 (2):158-186

Wahab, S.,2013. Marketing Mix Dan Religi Terhadap Minat Masyarakat. Jurnal Manajemen Dan Akuntansi 2 (2):66-78

Wahab, W. 2016. Pengaruh Tingkat Bagi Hasil Terhadap Minat Menabung Di Bank Syariah. Jurnal Ekonomi Dan Bisnis Islam 1 (2):168-184

Wiedenfels, G. 2009. Trust of Potential Buyers in New Entrepreneurial Ventures.lst edition. Edition Wissenschaft. Entrepreneurship. Wiesbaden: Gabler

Wulandari dan Ekawati. 2015. Peran Kepercayaan Dalam Memediasi Persepsi Nilai Terhadap Niat Beli Produk Ramah Lingkungan. E-Jurnal Manajemen Unud. 4 (7) : 2095-2109

Yakin, I. A. 2016. Faktor-Faktor Yang Mempengaruhi Minat Nasabah Muslim Dan Non Muslim Terhadap Transaksi Pembiayaan Pada Perbankan Syariah. Jurnal Ekonomi Dan Bisnis Islam. 1 (2): 99-110.

Yazid A. A. 2017. Faktor-Faktor Yang Mempengaruhi Minat Muzakki Dalam Menunaikan Zakat di Nurul Hayat Cabang Jember. Economic. Jurnal Ekonomi dan Hukum Islam ( 2) :173-199

Yu, C.S. 2012. Factors Affecting Individuals To Adopt Mobile Banking: Empirical Evidence From The UTAUT Model. Journal of Electronic Commerce Research 13(2): 104-121

Zaheer, A., dan R. Bachmann, 2006. Handbook Of Trust Research. Massachusetts: Edward Elgar Publishing, Inc. 